\title{
Gravity Concentration of Minerals - Natural Phenomena and Industrial Practice
}

\author{
R. Bhima Rao ${ }^{1 *}$, Y. Lokeswara Reddy ${ }^{2}$ \\ ${ }^{1 *, 2}$ CSIR-Institute of Minerals and Materials Technology Bhubaneswar-751013, India
}

\begin{abstract}
Archeological evidence indicates that the gravity concentration commenced before introducing the metallurgy technology. Nature comminutes the rock into individual liberated particles by weathering processes and transport them to downslope through geological agencies such as rivers, wind, and glaciers. During this process, the morphology of the Earth's crust changes and exhibits a distinctive topography - representing a model of a gravity unit and a process of concentration of heavy minerals by geomorphic agencies similar to the gravity concentration mechanism at industries. In this paper, the gravity concentration by nature and by industrial practices are compared and discussed.
\end{abstract}

Keywords: Gravity concentration, Geomorphic agencies, Mineral separation, Mineral beneficiation.

\section{Introduction}

Since the very dawn of civilization, i.e. Paleolithic (500000 BC) age, man-made use of natural-gravity- sorted stones, pebbles and rocks as hunting instruments. As knowledge increased so did man's need for better tools and ornamentation. The native metal gold was first recognized during Neolic ( $8000 \mathrm{BC}$ age and concentrated deposits were started [1]. In due course of time, because of its scarcity, the crude forms of industrial gravity concentration techniques took birth in the Chalcolithic age (4200 BC) in the field of gold collection. Since then the gravity concentration remained a dominant concept in mineral processing industries.

Gravity concentration" and "Mechanical concentration" referred to by mineral engineers and geologists respectively are synonymous processes that describe the separation of minerals based on the difference in their densities. On the Earth's crust, the heavier minerals become concentrated into deposits by moving water such as streams, rivers or air. Such deposits are known as "Placer deposits" and such processes of formation of mineral deposits are called mechanical concentrations [2]. Whereas such process of concentration of heavy minerals at industries by using mineral separation equipments and instruments is called as gravity concentration [3]. The mechanical concentration of

*Corresponding Author: e-mail: dr.r.bhimarao@gmail.com,

Tel-+91-9437576006

ISSN 2320-7590

(C) 2020 Darshan Institute of Engg. \& Tech., All rights reserved mineral deposits chiefly depends on the geomorphology (morphology of the Earth's crust) and geomorphic agencies such as rivers, oceans, wind etc. Similarly, in industries, the gravity concentration of mineral-sands depends on the design of gravity equipments. In this paper, the influence of geomorphology and its agencies on the mechanical concentration of mineral deposits and simulation of these processes and concentration techniques with gravity separation units and its operating principles are discussed.

The mechanical/ gravity concentration not only depends on the principle of difference in specific gravity of minerals but also depends on the size and shape of the particles as mentioned in Table 1.

Table 1. Effect of concentration criterion on gravity concentration

\begin{tabular}{|l|l|}
\hline 1.25 & Separation is possible at gravel sizes \\
\hline 1.50 & $\begin{array}{l}\text { Separation is difficult but can be applied } \\
\text { commercially up to 2 mm in size }\end{array}$ \\
\hline 1.75 & $\begin{array}{l}\text { Commercial separation is possible down to 150 } \\
\text { microns }\end{array}$ \\
\hline 2.00 & Reasonable separation is possible \\
\hline 2.50 & $\begin{array}{l}\text { The clean concentrate can be obtained with a large } \\
\text { tonnage of middlings but difficult to get low-grade } \\
\text { tailing }\end{array}$ \\
\hline 3.00 & $\begin{array}{l}\text { Gravity separation is possible at all sizes down to } \\
\text { fine sands }\end{array}$ \\
\hline
\end{tabular}




\section{Geomorphology and its agencies for gravity concentration}

In the formation of placer deposits, nature has operated through the weathering process (Table 2) to produce the results achieved by a man when he mines, crushes and concentrates ores. When weathering yields debris on a hill slope, the heavier particles move downslope more slowly than the lighter ones, giving a rough concentration into eluvial placers. During water transportation, the concentration may occur in streams, giving stream placer or alluvial deposits, or on beaches, giving beach placers. If concentration takes place by wind, eolian placers result. Thus due to such a natural process of formation of placer deposits, the morphology of the Earth's crust changes and exhibits different topography. Typical worldwide recognized topographic expressions of placer deposits are shown in Table 3. The physical characteristics [4] and the concentration criterion of these minerals are shown in Table 4. The basic principles in the formation and concentration of these deposits are simulated with the industrial gravity concentration units and its operating principles which are discussed below.

Table 2. Weathering progress

\begin{tabular}{|l|l|l|l|l|}
\hline Agency involved & $\begin{array}{l}\text { The process by which } \\
\text { loosened material is } \\
\text { acquired }\end{array}$ & $\begin{array}{l}\text { The process by } \\
\text { which earth surfaces } \\
\text { are eroded materials } \\
\text { in transit }\end{array}$ & $\begin{array}{l}\text { Process of wear } \\
\text { materials while in } \\
\text { transit }\end{array}$ & Methods of transport \\
\hline Running water & $\begin{array}{l}\text { Hydraulic/fluviraption } \\
\text { or chemical reaction }\end{array}$ & $\begin{array}{l}\text { Corrosion or } \\
\text { abrasion }\end{array}$ & Attrition & $\begin{array}{l}\text { Traction saltation } \\
\text { suspension solution } \\
\text { flotation }\end{array}$ \\
\hline Waves and currents & $\begin{array}{l}\text { Hydraulic or } \\
\text { fluviraption }\end{array}$ & $\begin{array}{l}\text { Corrosion or } \\
\text { abrasion }\end{array}$ & Attrition & $\begin{array}{l}\text { Traction saltation } \\
\text { suspension solution } \\
\text { flotation }\end{array}$ \\
\hline Wind & Deflation & $\begin{array}{l}\text { Corrosion or } \\
\text { abrasion }\end{array}$ & Attrition & $\begin{array}{l}\text { Traction saltation } \\
\text { suspension solution }\end{array}$ \\
\hline Glaciers & $\begin{array}{l}\text { Souring plucking or } \\
\text { sapping }\end{array}$ & $\begin{array}{l}\text { Corrosion or } \\
\text { abrasion gouging }\end{array}$ & Attrition & Traction suspension \\
\hline Groundwater & Chemical reaction & Corrosion & - & Solution \\
\hline
\end{tabular}

Table 3. Effect of geomorphic process on concentration of minerals

\begin{tabular}{|l|l|l|}
\hline Topography & Process of formation/agencies involved & Placer deposit \& Occurrence in India \& elsewhere \\
\hline 1) Eluvial & $\begin{array}{l}\text { Washed/blown out by rainwater/wind } \\
\text { at foothills }\end{array}$ & $\begin{array}{l}\text { Tungsten, Degana, Rajasthan Apatite, Visakhapatnam, AP } \\
\text { Corundum\& sapphire, Adyal foothills, Maharashtra, India. }\end{array}$ \\
\hline 2) Colluvials & $\begin{array}{l}\text { Produced by creep } \\
\text { downslope/gravitational forces of } \\
\text { residual materials. The transition } \\
\text { between residual/alluvial }\end{array}$ & $\begin{array}{l}\text { Gold, California, Australia, Newzealand, Columbite- } \\
\text { tantalite, Mamundur, India. }\end{array}$ \\
\hline 3) Alluvials & Rivers & $\begin{array}{l}\text { Gold, Sierra Nevada and Klamath mountain by the tertiary } \\
\text { river, California, Platinum Russia, Colombia, Tin, Malaya, } \\
\text { Diamonds, Vaal and orange river dist, South Africa, } \\
\text { Belgian, Brazil etc. Diamonds, Panna, MP, India. }\end{array}$ \\
\hline 4) Eolin & Wind/dunes & $\begin{array}{l}\text { Gypsum dunes, White sands national monument, New } \\
\text { Mexico, Gold, Australia, California, Shoreline dunes, AP, } \\
\text { India. }\end{array}$ \\
\hline 5) Beach & $\begin{array}{l}\text { Sold, California, Alaska, Diamonds, Namaqualand dt, } \\
\text { South Africa, Monazite, Ilmenite, India. }\end{array}$ \\
\hline 6) Glacial & $\begin{array}{l}\text { the drift of Ice-formation \& melting } \\
\text { due to seasonal variation found in the } \\
\text { sand and gravels of valley trains and } \\
\text { end moraines }\end{array}$ & Gold, Tarryal area, Park country, Colorado \\
\hline $\begin{array}{l}\text { 7) Ancient/buried } \\
\text { placers }\end{array}$ & $\begin{array}{l}\text { Due to landslides, mud/lava flows, } \\
\text { glacial drift marine sediments or later } \\
\text { alluvium }\end{array}$ & Tin, Malaysia, Gold, Tertiary valleys. \\
\hline 8) Laterisation & Wind dunes & $\begin{array}{l}\text { Redsediments/Nalli sediments/Teri sands/Shoreline dunes, } \\
\text { AP, India. }\end{array}$ \\
\hline
\end{tabular}


Table 4. Physical characteristics and concentration criterion for gravity concentration of common placer minerals

\begin{tabular}{|c|c|c|c|c|c|c|}
\hline \multirow[t]{2}{*}{ Mineral } & \multirow[t]{2}{*}{ Hardness } & \multirow[t]{2}{*}{$\begin{array}{l}\text { Relative } \\
\text { density }\end{array}$} & \multicolumn{2}{|c|}{$\begin{array}{c}\text { Concentration } \\
\text { criterion }\end{array}$} & \multirow{2}{*}{$\begin{array}{l}\text { Common } \\
\text { mesh size } \\
\text { microns }\end{array}$} & \multirow[t]{2}{*}{ Weathered shape } \\
\hline & & & Water & Air & & \\
\hline Apatite & 5 & $3.1-3.2$ & 1.3 & 1.2 & 150 & $\begin{array}{l}\text { Rounded elongated (egg-shaped) } \\
\text { grains, stumpy euhedral prisms }\end{array}$ \\
\hline Cassiterite & 6.7 & $6.8-7.1$ & 3.7 & 2.7 & $150-63$ & $\begin{array}{l}\text { Prisimatic,angular, rounded, } \\
\text { fractured grains/fragments }\end{array}$ \\
\hline Chromite & 5.6 & $4.3-4.6$ & 2.2 & 1.7 & $355-105$ & $\begin{array}{l}\text { Octahedral crystals, subrounded to rounded grains, } \\
\text { irregular fragments }\end{array}$ \\
\hline Columbite & 9 & $5.1-5.2$ & 2.6 & 2.0 & Various & Fracture fragments and sub rounded grains \\
\hline Corundum & 9 & $3.1-4.2$ & 1.9 & 1.6 & $1204-5000$ & Irregular fracture fragments sometimes rounded \\
\hline Diamond & 10 & 3.5 & 1.6 & 1.3 & Various & Octahedral crystals, rounded \\
\hline Garnet(var) & 7 & $3.4-4.3$ & 1.8 & 1.5 & $1204-150$ & Commonly irregular, fractured \\
\hline Gold & 2.5 & 19.3 & 11.4 & 7.4 & $3353-75$ & $\begin{array}{l}\text { Rpunded/flattened grains, rods wirelike } \\
\text { pellets/flakes }\end{array}$ \\
\hline Hornblende & 5.6 & $4.0-4.4$ & 2.0 & 1.6 & $250-75$ & $\begin{array}{l}\text { Platy, cleavage flakes, some with raggedends, } \\
\text { rounded prisms }\end{array}$ \\
\hline Ilmenite & 5.6 & $4.5-5.0$ & 2.3 & 1.8 & $300-100$ & $\begin{array}{l}\text { Irregular subrounded-rounded grains usually } \\
\text { equidimensional }\end{array}$ \\
\hline Leucoxine & Variable & $3.5-4.5$ & 1.9 & 1.5 & $1204-75$ & $\begin{array}{l}\text { Rounded-subrounded, angular pitted irregular } \\
\text { grains }\end{array}$ \\
\hline Magnetite & 6 & $5.1-5.2$ & 2.6 & 2.0 & $1204-150$ & $\begin{array}{l}\text { Occassion octahedral crystals angular and well } \\
\text { rounded, irregular equidimensional }\end{array}$ \\
\hline Monazite & 5.2 & 4.6-5.4 & 2.5 & 1.9 & $500-100$ & $\begin{array}{l}\text { Rare crystals, well-rounded grains, usually } \\
\text { ellipsoidal, occasion sub euhedral tablets }\end{array}$ \\
\hline Olivine & 6.7 & $3.2-3.4$ & 1.6 & 1.3 & 250 & $\begin{array}{l}\text { Usually irregular and much fractured rarely } \\
\text { euhedral }\end{array}$ \\
\hline Rutile & 6.3 & $4.1-4.3$ & 2.0 & 1.6 & $1204-75$ & $\begin{array}{l}\text { Prisimatic, broken, rounded anhedral, fracture, } \\
\text { twins }\end{array}$ \\
\hline Sphene & 5.3 & 3.5 & 1.6 & 1.3 & Various & $\begin{array}{l}\text { Occassionally diamond shape commonly } \\
\text { irregular/subrounded }\end{array}$ \\
\hline Spinel & Various & $3.6-4.6$ & 1.9 & 1.6 & $1204-150$ & Rounded, octahedral grains \\
\hline Staurolite & 7.3 & 3.6 & 1.7 & 1.4 & $500-150$ & Usually irregular-platy \\
\hline Tantalite & 6.3 & 7.9-8.0 & 4.3 & 3.1 & Various & Fractured, irregular, subround \\
\hline Tourmaline & 7.3 & $2.9-3.2$ & 1.3 & 1.2 & $250-100$ & Well rounded, angular, fractured \\
\hline Wolframite & 5.3 & 7.1-7.9 & 4.1 & 2.9 & Various & Submetallic cleavage fragments \\
\hline Xenotime & 4.5 & 4.6 & 2.3 & 1.8 & $500-100$ & $\begin{array}{l}\text { Commonly rounded, sub angular rectangular } \\
\text { flakes }\end{array}$ \\
\hline Zircon & 7.5 & $4.2-4.9$ & 2.3 & 1.8 & $1204-75$ & $\begin{array}{l}\text { Prisimatic, stumpy pyramidal crystals, rounded } \\
\text { grains, fractured fragments }\end{array}$ \\
\hline
\end{tabular}

\section{Eluvial Placers}

The mechanical concentration of eluvial deposits is a typified process of preconcentration by means of size classification and desliming practice that existed in mineral processing industries. Eluvial placers may be considered an intermediate or embryonic stage in the formation of a stream or beach placers. They are formed from weathered lodes upon hill slopes. The heavier, resistant minerals collect below the outcrop, the lighter nonresistant products are swept downhill by rain wash or are blown away by wind or dissolved. This brings about a partial concentration by the reduction in volume. Gold placers of this type are found in California, Australia, New Zealand, and elsewhere are examples. The similarity of concentration of heavy minerals by geomorphic agencies and gravity concentration mechanism at industries is shown in Figure 1

\section{River or alluvial placers}

The geomorphic terms such as youth, maturity, and old age are commonly used to designate the stages of development of streams or rivers. In general river water, although everflowing downstream, does so with irregularity, it rushes through canyons sweeping everything along with it; it slackens in wide places; it swirls around the outside of bends, creating back eddies on the inside; it laps up over bottom projections, forming quiet eddies on the lee side [5]. During 
these processes and the development of river stages the earth's surface changes to distinctive characteristic landscapes. Each such typical landscape represents a model of gravity unit and its concentration mechanism. A few of these are shown in Table 5 and discussed below.

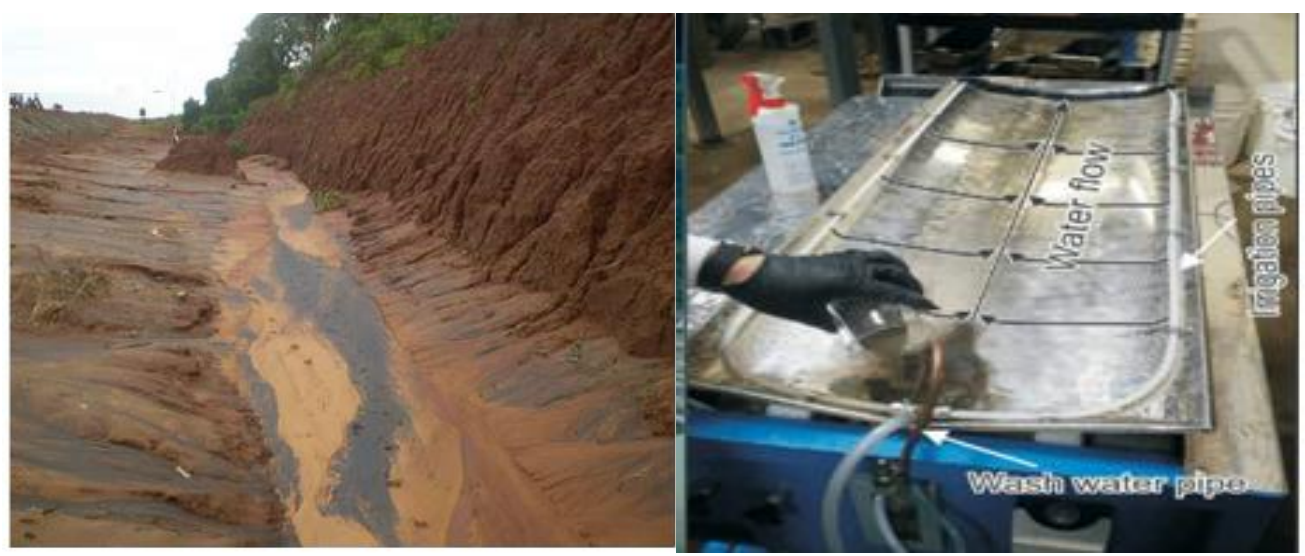

Figure 1. Concentration of minerals by Alluvial fans and Mineral separator flat tray

Table 5. Simulation of the geomorphic process to model gravity unit/mechanism

\begin{tabular}{|l|l|}
\hline Geomorphic process \& agencies model gravity unit & Simulated to industrial gravity unit \\
\hline Meanders & Spirals \\
\hline Sea tides & Jigs \\
\hline Natural riffles & Gravity tables \\
\hline Youth river/V-profile & Mineral separator V-tray \\
\hline Confluent alluvial fans & Mineral separator flat tray \\
\hline Cyclones-in desert/sea & Air/hydro cyclones \\
\hline
\end{tabular}

\section{V-shaped cross profile}

The landscape (Figure 2) developed by the youth stage river is similar to the design of the Mineral separator's V-tray (Figure 2) gravity unit, manufactured by M/s Bartley Mozley Company Ltd. The youth stage develops with few trunk streams and large tributaries. Numerous short tributaries and gullies will be extending themselves by headward erosion and developing the dendritic valley system. Valleys will have Vshaped cross profiles (Figure 2) and will be shallow or deep depending upon the height of the region above sea level. Due to seasonal rains and floods, the slimes, pebbles before and minerals will be transported to the downgradient of the Vshaped valley. Since the water velocity moderate to high depending on the topography, the slimes, pebbles of phosphate rock of alluvial origin occur in streams in Florida are the best example. Thus the process of mechanical concentration of minerals by dendritic V-shaped valley system represents the mechanism of V-tray wash water system and concentration. Alluvial placers of gold, tin, chromite, etc. (Table 3) are the example. The similarity of concentration of heavy minerals by geomorphic agencies and gravity concentration mechanism at industries is shown in Figure 2

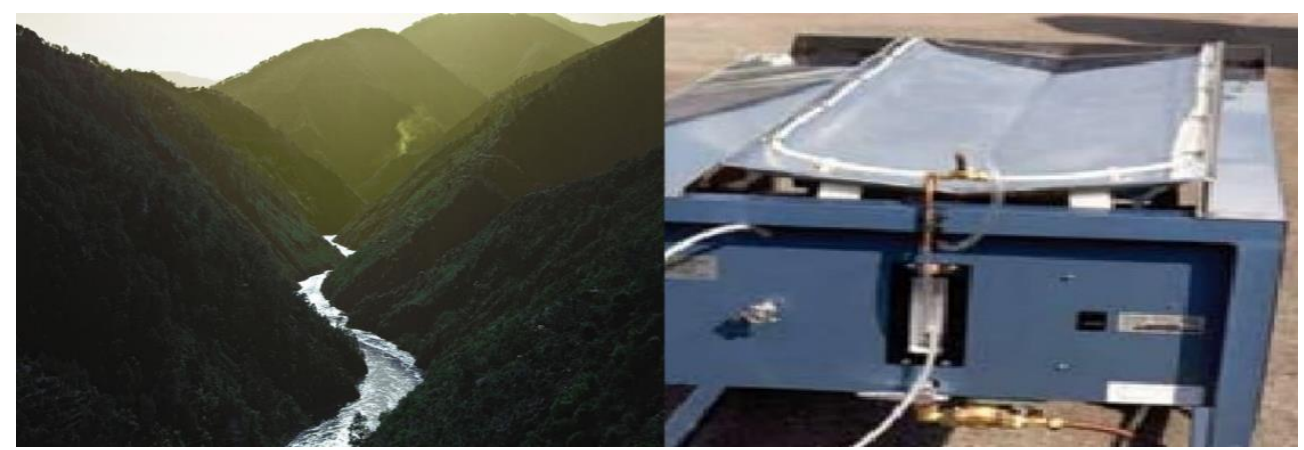

Figure 2. Concentration of minerals by Youth river V-profile and Mineral separator V-tray 


\section{Meanders}

During the mature stage of the river, the water velocity reduces, the $\mathrm{V}$-shaped valley widens and the landscapes such as meanders, a widening or a flow round course of river forms. The meander shape and mechanical concentration of minerals are similar to the design [6-8] and operation of the spiral concentrator (Figure 3). In a rapidly flowing meandering stream, the fastest water is on the outside curve of meanders and slack water is the opposite. The Junction of the two, where gravel bars form, is a favorable site for the deposition of placer minerals. Alluvial Placer deposits (Table 3) from all over the world are the best examples Placer deposits are concentrated along the meanders and at the down stream along the coastal line. The placer minerals are disintegrated from the parental rock due to differential weathering and transported by rainwater and rivers to the coastal shoreline. The placer heavy minerals are concentrated at the east coast of India contains $20 \%$ total heavy minerals. These are further concentrated by using industrial spirals up to $98 \%$ by weight. IREL, a public sector of atomic energy, Govt of India is one of the example for this process of concentration [9]. The similarity of concentration of heavy minerals by geomorphic agencies and gravity concentration mechanism at industries is shown in Figure 3.

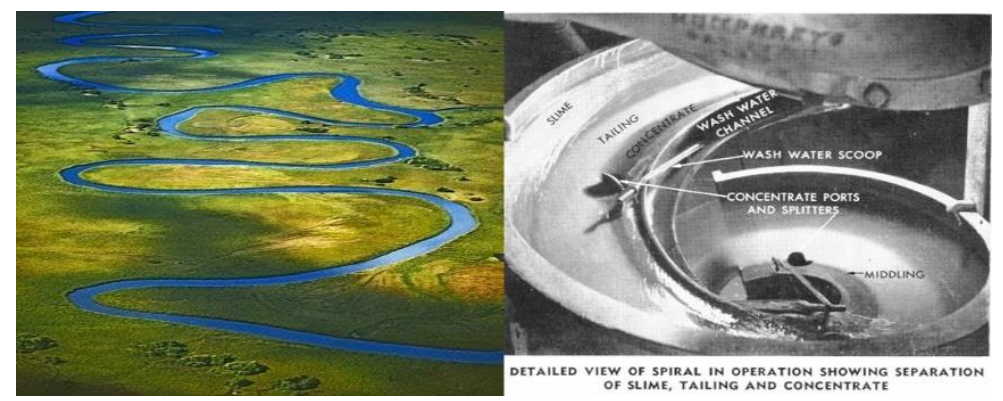

Figure 3. Concentration of minerals by Meanders and Spiral concentrator

\section{Natural riffles}

Where streams cross highly inclined or vertically layered rocks, such as slates, schists, or alternating hard and soft beds, the harder layers tend to project upward and the softer ones to be cut away [10]. This forms "Natural riffles" as shown in Figure 4, similar to the wooden riffles nailed on the top of the gravity table or in the bottom of a sluice box to arrest the heavier minerals in tabling or sluicing operation
The concentration of gold from the mother lode (Table 3 ) is the best example. The gold ore is normally found in two forms. (1) in the Quartz mineral known as Auruferrous quartz and (2) in the Sulphide deposits. The Auruferrous quartz, in general ground and subjected to gravity table for preconcentration of gold from $0.01 \%$ Au to $1 \% \mathrm{Au}$ [11]. The similarity of concentration of heavy minerals by geomorphic agencies and gravity concentration mechanism at industries is shown in Figure 4

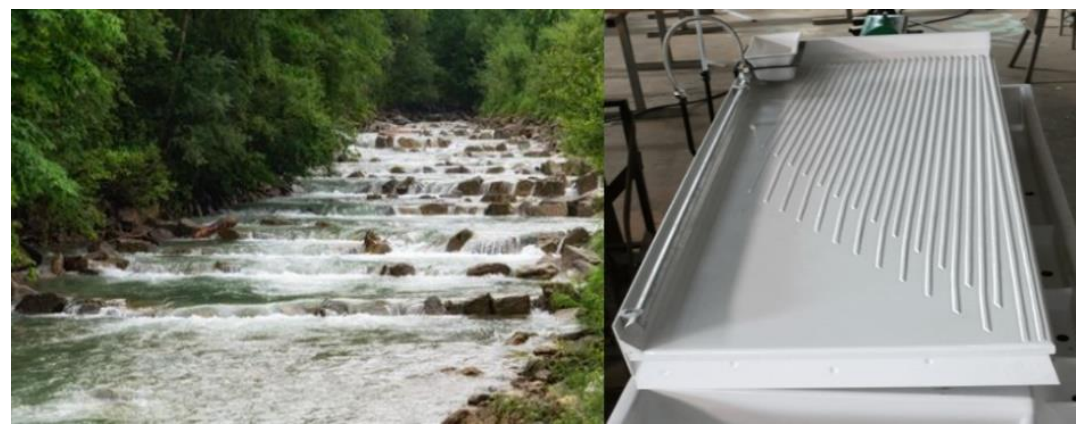

Figure 4. Concentration of minerals by Natural riffles and mineral separator gravity table

\section{Swirls and eddies}

Swirls and eddies quite commonly occur in the youth and mature stages of rivers. The concentration of minerals is based on the concept of particles in suspensions which are more readily moved by flowing fluid than one at rest. The process of concentration is similar to jigging and tabling gravity units. The eddies in streams or shore currents rise light substances from the bottom and enable currents to swish them away. Separation of light minerals from heavy ones is thus aided in bringing about concentration Also the swirls and eddies of stream and wave action simulate upward pulsations of jigs and tables in ore dressing by which lighter minerals are bounced higher than heavier ones so that they can be more easily moved away by flowing water. In streams, jigging action is particularly effective in concentrating placer 
minerals in the bottom gravels. Alluvial placers (Table 3) of gold, tin, platinum are the best examples

\section{Beach placers}

Beach placers are similar to the operation of jigs and tabling. Shore currents shift materials along the shore and the lighter materials are moved faster and farther than the heavy, thereby concentrating the heavy minerals. Wave action operates at the same time. Pounding waves pick up all available offshore materials indiscriminately (Figure 5) and throw them up on the beach, the back-wash and the undertow selectively pulls the light and finer materials seaward which in turn is moved alongshore as it has less kinetic energy. The larger and heavier materials throwing up of material from the underground slope on to the beach by breaking waves and its subsequent sorting by the back-wash lead to the formation of beach placers. Indian beach deposits (Table 3) of ilmenite, rutile, zircon, etc., are the best examples for beach placers. Most of the Chromite is liberated at coarse size during Comminution process. The crushed ore is usually subjected to Jigging process. In this process, the ore from 10-15\% $\mathrm{Cr} 2 \mathrm{O} 3$ can be upgraded to $40-45 \% \mathrm{Cr} 2 \mathrm{O} 3$. There are many chromite ore beneficiation process plants are existed in India and abroad [12]. The similarity of concentration of heavy minerals by geomorphic agencies and gravity concentration mechanism at industries is shown in Figure 5

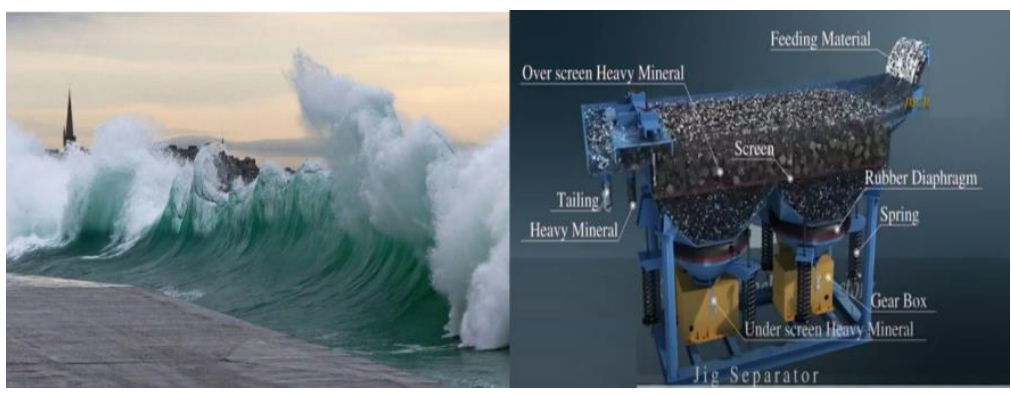

Figure 5. Concentration of minerals by Sea tides and Jig separator

\section{Eolin placers}

Wind instead of water may act as the agent of concentration and give rise to placer deposits. The process of formation of these deposits is similar to air cyclones and air tables. The light decomposed materials have been blown away; the heavy particles like gold, freed from their matrix, remained behind the continuation of this process finally resulted in patches of surface accumulation of placer gold in the debris of sand and wind-worn pebbles. Eolian placer gold deposits of Australian deserts and gypsum dunes in white sands, Mexico are the best examples. Hydrocyclones are normally used to separate fines from the coarse. In general iron ores, manganese ores, etc., are very commonly used. However, the use of cyclones for the recovery of super fine Kaolin clay is a widely accepted process. There are series of cyclones are used in Kaolin clay or iron ore industries [13]. The similarity of concentration of heavy minerals by geomorphic agencies and gravity concentration mechanism at industries is shown in Figure 6.
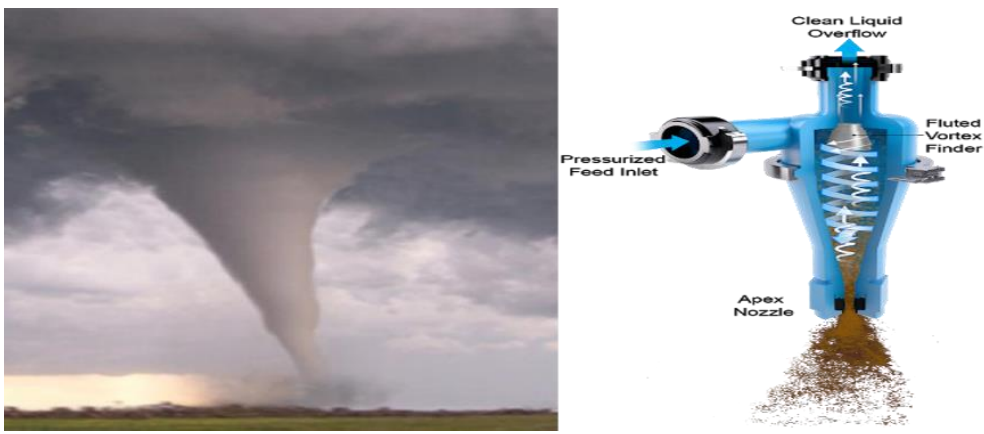

Figure 6. Concentration of minerals by Natural cyclones and Mineral separator Hydro cyclones

\section{Conclusions}

"Gravity concentration" and "Mechanical concentration" referred to by minerals engineers and geologists respectively are synonymous processes that describe the separation of minerals based on the difference in their densities. The mechanical concentration of mineral deposits depends on the geomorphology and geomorphic agencies. Concentration may occur by streams, giving placer or alluvial deposits, or on beaches, giving beach placers. If concentration takes place by wind, eolian placers result. The basic principles in the formation of meanders, natural riffles, swirls, eddies, etc. and the concentration of these deposits are similar to the 
industrial gravity concentration units such as spirals, jigs, tables, cyclones, etc. and their operating principles

\section{References}

1. Wolfe, J.A., "Mineral Resources - a world review".

2. Bateman, A.M., "Economic Mineral Deposits", Asia publishing house, Bombay, 1962, 227-44.

3. Sunita Routray, Ranjita Swain, Raghupatruni Bhima Rao, "Optimization of Mineral Separator for Recovery of Total Heavy Minerals of Bay of Bengal using Central Composite Design" Journal of The Institution of Engineers (India): Series D 98, 119-130(2017).

4. Australia Publishing, "Minerals Sands in Asia \& Pacific", Bureau of Mineral References, Geology \& Geophysics, Vol. 4, p.5.

5. Manuel E. Camacho, Adolfo Quesada-Román, Rafael Mata, Alfredo Alvarado, "Soil-geomorphology relationships of alluvial fans in Costa Rica" Geoderma Regional 21 (2020) e00258.

6. Wills, B.A., "Mineral Processing Technology", Gravity Concentration Chapter, Pergamon Press, Oxford, New York, $4^{\text {th }}$ edition, 1988.
7. Reichard O. Burt, "Gravity Concentration Technology", Developments in Mineral Processing, 5, Elsevier Science Publishers B.V the Netherlands, 1984.

8. Ernst C. Nienaber, Lidia Auret, "Experimental modeling and plant simulation of spiral concentrators: Comparing response surface methodology and extended HollandBatt models" Minerals Engineering 141 (2019) 105833.

9. Indian Rare Earths Limited website https://www.irel.co.in

10. Xiaoqi Chen, Minghui Yu, Changjie Liu, Huamei Liu, "Recent adjustments of pool-riffle distribution along the channels in the Pearl River Delta, China" Ocean and Coastal Management 186 (2020) 10509.

11. Hutti Gold Mines Company Limited website http://www.huttigold.co.in

12. Ferro Alloys Corporation Limited (FACOR) website http://www.facorgroup.in

13. Haydn H.Murray, "Major Kaolin Processing Developments", International Journal of Mineral Processing, 7 (1980) 263-274.

\section{Biographical notes}
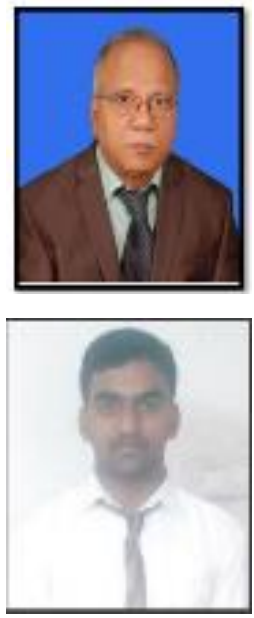

Dr. Raghupatruni Bhima Rao, Formerly Chief Scientist in CSIR-Institute of Minerals and Materials Technology, Govt. of India, Bhubaneswar, is currently Director, Aryan Institute of Engineering Technology [Bijupatnaik University of Technology], Bhubaneswar and Advisor, IREL, Department of Atomic Energy, Chatrapur. He is also Chairman and committee member for different professional societies. To his credit he has a few patents and more than 250 publications in International and National journals. He is editorial member for few National and International journals. He has obtained doctorate degree in Mineral Engineering from IIT Dhanbad [the then Indian School of Mines, Dhanbad] after completion of his double post graduation from College of Science and Technology and College of Engineering, Andhra University, Visakhapatnam. He has gained in-depth knowledge and experience in the fields of Mineral Process Engineering

Mr. Y. Lokeswara Reddy is a Research Scholar in CSIR-Institute of Minerals and Materials Technology, Govt. of India, Bhubaneswar, has received B.Tech degree in Metallurgical and Materials Engineering from Rajiv Gandhi Univeristy of Knowledge Technologies (RGUKT, R.K. Valley), Andhra Pradesh in 2017. His research interests are of Mineral beneficiation, Biodegradable alloys for biomedical applications, Mechanical alloying of light weight alloys \& composites and Characterization, Root cause failure analysis 